\title{
Equity from an Institutional Perspective in the Romanian Higher Education System
}

\author{
Jamil Salmi, Cezar Mihai Hâj and Daniela Alexe
}

Keywords Higher education policy - Equity promotion policy • Equity • Scholarship system • Merit-based and need-based scholarships • Under-represented groups - Student dorms - Tuition fees - Social services

\section{List of Abbreviations}

NIS National Institute for Statistics

EHEA European Higher Education Area

NRP National reform plan

CNFIS National Council for Higher Education Funding

\section{Introduction}

Even though, Romania has participated into the Bologna Process since 1999, and as signatory country has taken several commitments regarding national policies in order to achieve the goals of the Bologna Process, which is the consolidation of the

\footnotetext{
J. Salmi ( $₫)$

Global Tertiary Education Expert, Bogota, Colombia

e-mail: jsalmi@tertiaryeducation.org

C.M. Hâj · D. Alexe

Executive Agency for Higher Education, Research, Development and Innovation Funding (UEFISCDI), Bucharest, Romania

e-mail: cezar.haj@uefiscdi.ro

D. Alexe

e-mail: daniela.alexe@uefiscdi.ro

C.M. Hâj

National University of Political Studies and Public Administration (SNSPA),

Bucharest, Romania

(C) The Author(s) 2015

A. Curaj et al. (eds.), Higher Education Reforms in Romania,

DOI 10.1007/978-3-319-08054-3_4
} 
European Higher Education Area (EHEA), ${ }^{1}$ no analysis exists to this day regarding how these commitments have actually translated into national policy, especially regarding equity.

Furthermore, looking at the Romanian higher education system, one can see that even though the country has a legislative framework that targets equity, data regarding participation rates of various under-represented or disadvantaged groups show that these policies are not effective, "Romania having one of the lowest scores compared with other EU states" (NRP 2009-2013).

Also, in order to understand why these policies have not achieved their goals, it is necessary to see how universities understand and implement these policies at the institutional level. In this context, the main objectives of the present article are to analyse how Romania's commitments regarding equity in higher education within the Bologna Process are translated into national policies and how Romanian universities implement them, looking in particular at the policies regarding student accommodation (students dorms) and at the scholarship system as means of enhancing equity in higher education.

Starting from Romania's commitments within the Bologna Process in the European context, and placing them in an appropriate theoretical context, the article will present a snapshot of the current trends in a comprehensive manner to see if and how equity is on the public agenda. Then it will analyse the main national policies in Romania that are influencing or could influence equity in higher education, what has been done until now and what the available data shows with regard to equity. Once the general setting has been analysed, the article will go into depth to analyse institutional behaviours regarding equity and how the most important policies identified in this article are translated into institutional policies and actions.

The article is based on the work carried out by the authors within the project "Higher Education Evidence Based Policy Making: a necessary premise for progress in Romania" implemented by the Executive Agency for Higher Education, Innovation and Development Funding (UEFISCDI), ${ }^{2}$ in which analysis were made regarding Romania's commitments within the Bologna Process and regarding equity within a sample of universities.

Methodologically, the authors relied on desk research, a self-assessment instrument, and study visits. The desk research included gathering and analysing information from the national legal framework, official papers released by international and national institutions and research articles or perception studies in the field of equity in higher education. Also, it implied gathering and analysing data provided mainly by the National Institute for Statistics (NIS), ${ }^{3}$ Ministry of National Education and National Council for Higher Education Funding (CNFIS). The selfassessment instrument was developed by the International Association of Universities (IAU) in 2010 and modified in 2013, in the context of the UEFISCDI project

\footnotetext{
${ }^{1}$ Further, the article uses the abbreviation EHEA for the European Higher Education Area.

2 Reference: http://www.politici-edu.ro/?lang=en.

3 Reference: NIS (2013).
} 
mentioned above, in order to fit into the Romanian context. Its implementation aimed at gathering information regarding institutional policies and data on equity in higher education. The self-assessment instrument was applied in four universities. The study visits were conducted in the same four Romanian universities with different profiles (public and private, from Bucharest and other university centres) through semi-structured interviews that included relevant university representatives and stakeholders (rectors, senate members, administrative staff, teachers and students). The paper also draws on the various authors' knowledge which includes indepth experience at the World Bank, universities, the ministry of education, national student's union and the Romanian Bologna Secretariat (2009-2012).

\section{Setting the Background}

The concept of "equity" in higher education can have several meanings depending on the perspective used. In a recent article, Salmi and Bassett stressed the importance of equity for fairness and efficiency purposes. The economic efficiency argument in favour of equity promotion is related to the development of human resources and the capacity to capture economic and social benefits. The example given is that of a talented, low-income and/or minority high school graduate who is denied entry into tertiary education, thus representing an absolute loss of human capital for the individual person and for society as a whole (Salmi and Bassett 2014). Another perspective refers to the equality of participation across ethnicities or socioeconomic backgrounds (Harper et al. 2009). This approach argues that the student body in higher education should reflect the distribution of socio-economic status and ethnicity/race within the population from which the student body is drawn (Astin and Oseguera 2004; Harper et al. 2009; Niemann and Maruyama 2005).

Though the article takes into consideration the various understandings of equity, the basis of the study is the Bologna Process and the EU's understanding regarding equity. The European Union's view on equity, as stressed in one of its communications, is "the extent to which individuals can take advantage of education and training, in terms of opportunities, access, treatment and outcomes" and the outcomes of education are "independent of socio-economic background and other factors that lead to educational disadvantage" (Commission of the European Union 2006).

Within the Bologna Process (to which Romania was one of the first adhering countries), assuming responsibility for the development of the social dimension of education was underlined by the Ministers responsible for education from the EHEA, for the first time, in a communication adopted at the Prague Ministerial Conference (2001). Subsequently this ideal was operationalized in political commitments regarding equity, access and completion of studies in higher education, through concrete government strategies and clear targets for enlarging access and raising participation. With the adoption of the London Communication (2007), the Ministers reaffirmed their political commitment to the principle of equity, defining it as: “... the student body entering, participating in and completing higher education 
at all levels should reflect the diversity of our populations. We reaffirm the importance of students being able to complete their studies without obstacles related to their social and economic background".

The concrete objectives regarding equity and access to higher education assumed by Romania, as a member of the European Higher Education Area (EHEA) following its Bologna Process commitments, are:

- Setting measurable targets for widening overall participation. Efforts to achieve equity in higher education should be complemented by actions in other parts of the educational system - Leuven (2009), Bucharest (2012);

- Strengthening policies of raising completion rates in higher educationBucharest (2012);

- Setting measurable targets for increasing the participation of under-represented groups in higher education-Leuven (2009), Bucharest (2012);

- Reporting national strategies, policies, action plans and measures to evaluate their effectiveness, in the field of social dimension-London (2007).

\section{Analysing Equity in the Romanian Higher Education System}

\subsection{Looking at the Strategic Policy Documents}

The Romanian policy objectives regarding higher education are put forward in national strategies and other policy documents. Analysing the governing program for 2013-2016, the chapters regarding education and youth mention the following objectives related to equity in higher education:

- Ensuring social equity policies;

- Stimulating the participation of the Roma population to higher levels of education;

- Ensuring complementary education for raising the ability to adapt to changing circumstances and rebuilding social cohesion through: developing educational alternatives, training youth through sports, rebuilding camps for pupils and students, institutionalizing the participation in projects and programs dealing with areas complementary to the curriculum;

- Stimulating youth from a rural background to go to school;

- Social scholarships need to ensure, each month, the expenses for meals, school supplies and housing necessary for students (Government of Romania 2013).

Another strategic document relevant for the purpose of this article is the National Pact for Education, signed in 2008 by all parliament political parties and by 22 civil society organizations. This policy document listed eight major objectives on which any new legislative framework should be based. One of which introduced the notion of "priority education areas" (areas in which measures should have been 
adopted with priority), in order to surpass the differences that dramatically separate the rural and urban environments or affect different categories of Romanian citizens (The National Pact for Education 2008).

Also, the National Reform Plan 2009-2013 (NRP) ${ }^{4}$ mentions the fact that Romania currently does not effectively encourage access to education, basing this statement on the fact that the country currently occupies one of the last positions in Europe regarding participation of youths aged 15-24.

Referring to social inclusion, the NRP reviews the policies in place developed by the Ministry of National Education regarding: rural population, Roma population, children with special educational requirements (CES), other vulnerable groups (children from socio-economical disadvantaged groups, home alone childrenchildren with parents that are working abroad, immigrants, and others) (Government of Romania 2009).

Even though no official singular document regarding the definition of disadvantaged and under-represented groups in higher education was found in the desk research phase, the authors considered the following groups to be of interest for the current study: female students, students coming from low income families (including working students), students from rural areas, students with disabilities and Roma students. These groups were identified based on the information available in analysed policy documents (such as special measures for inclusion in higher education which are already in place for certain groups), and by taking into account international practice and experience.

\subsection{Looking at the Data}

When addressing equity of higher education, it is necessary to look separately at its three dimensions: equity of access which means offering equal opportunities to enrol in universities, equity of results which relates to opportunities to advance in the system and to successfully complete tertiary level studies; and equity of outcomes which looks at the labour market outcomes of various groups (Salmi and Bassett 2014).

In this context, the authors took into consideration the data regarding secondary education, especially of those graduating from the Baccalaureate (as a first sine qua non legal condition for having access to higher education) and the data regarding the characteristics of the student body. The article will focus less on labour market outcomes of various groups because of the lack of available data.

Regarding secondary education, according to the NIS, for the time period 1995-2011, the evolution of the population at high school age (15-18 years) can be correlated with the evolution of the population from the same age enrolled in high school (Fig. 1).

\footnotetext{
${ }^{4}$ Further, the article will use the abbreviation NRP for the National Reform Plan.
} 


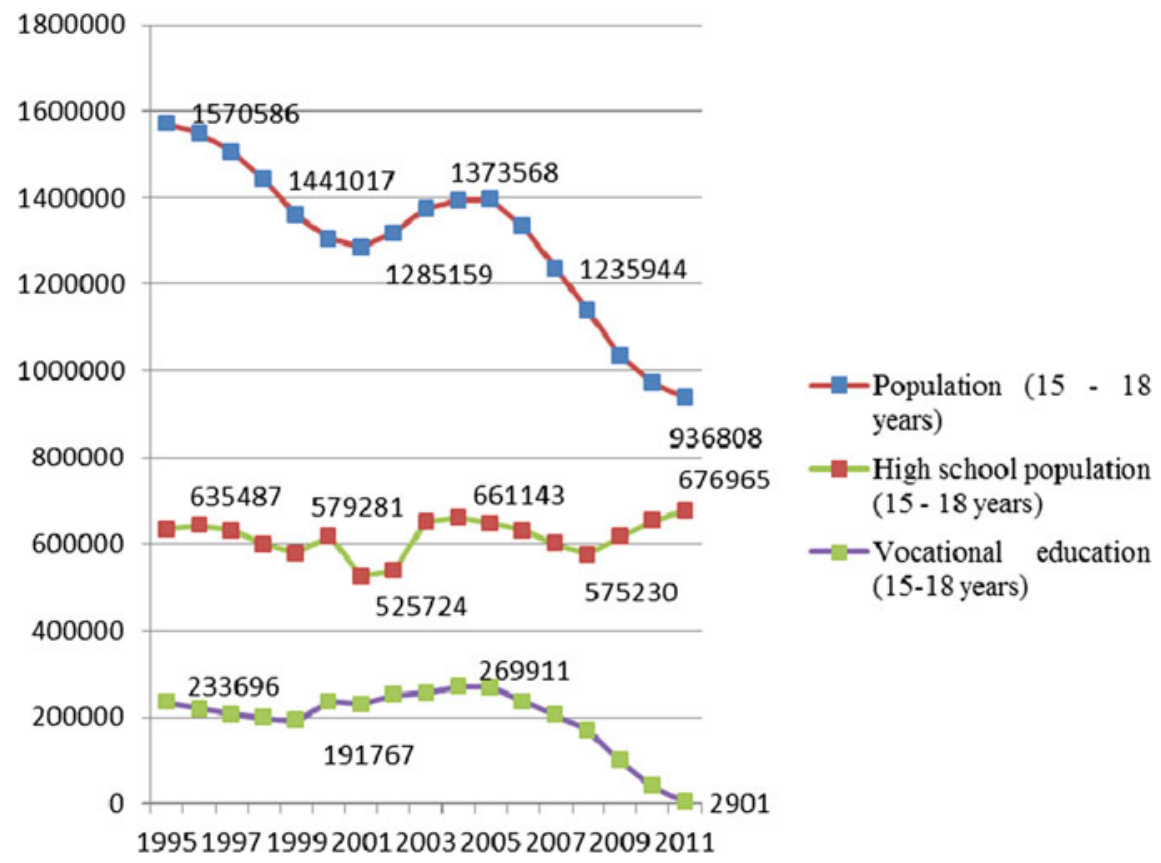

Fig. 1 Evolution of population, high school population and vocational education population (15-18 years), NIS

The data shows that the number of young people enrolled in vocational education started to drop in 2008, while the number of high schools students started to increase. This can be correlated with the government's decision to close trade schools, ${ }^{5}$ which redirected young people to high-schools. Nevertheless, according to the data provided by the NIS, the participation rate in high schools of population aged 15-18 years started to decrease in 2010, this decrease being stronger than the demographic decline. It can be concluded that there are also other factors influencing access to secondary education apart from demographics, one of them being the decision to close the trade schools.

A notable phenomenon affecting equity in higher education is the evolution of the number of high school students who have passed the baccalaureate, which has dramatically decreased from $81.4 \%$ in 2009 to $44.47 \%$ in 2011, mainly due to the multiple anti-fraud measures that were successfully introduced (Fig. 2).

Analysing the data provided by the NIS one can see that the decrease is primarily felt in private universities where the number of students enrolled in 2012, in the first year of study, at bachelor level, has decreased by $76.4 \%$ compared to 2007 .

${ }^{5}$ Reference: Order no. (77/2009). 


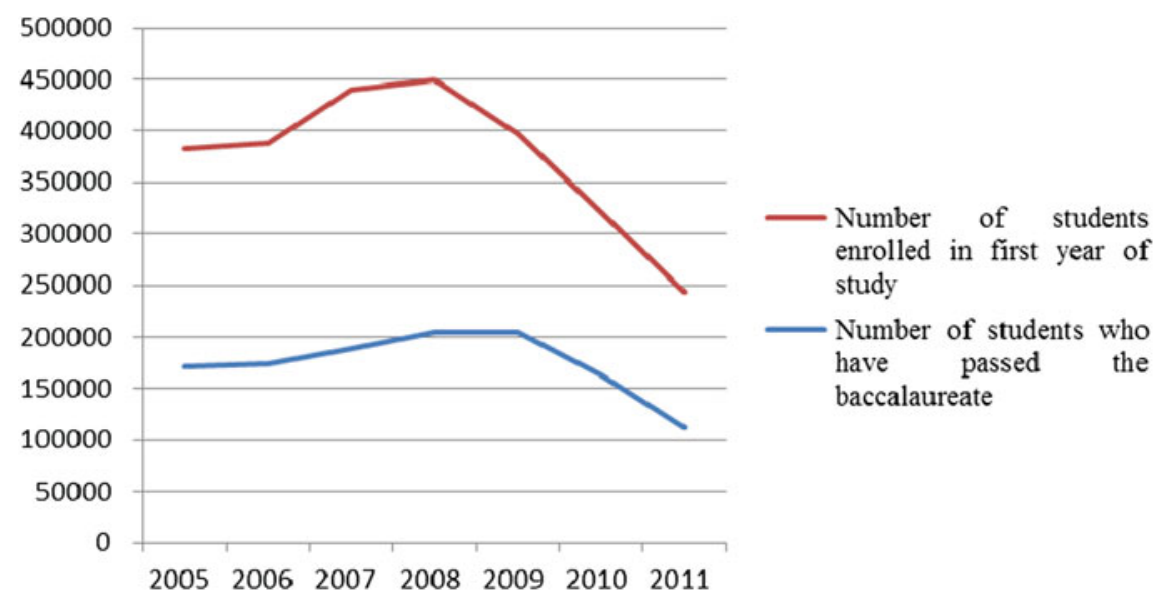

Fig. 2 Evolution of the number of students who have passed the baccalaureate, students enrolled in the first year-bachelor level. Reference Data from NIS and the National Assessment and Examination Center

Therefore, the decreasing number of students accessing higher education can be attributed at the same time to the demographic decrease of young population, the reduction in the high school population and of the lower success rate at the baccalaureate exam (Table 1).

Looking at the characteristics of the student body, especially at the data regarding the participation of disadvantaged/under-represented groups in higher education, the first remark could be that there is no official singular document defining and targeting these groups, even if there are international commitments that require such targets. ${ }^{6}$ Official policy documents tackle the issue of the low participation of some disadvantaged groups and others mention measures and policies in place (as described in above section), but there is no coherent policy framework regarding equity. However, by analysing the legal framework and the current policies, several instruments can be found for enhancing the inclusion of some specific groups, even if there is no correlation between their goals and specific measures at the national level. In this context, the authors found useful to include in the present article a short overview of the data regarding the participation of the groups considered under-represented (as described at the end of this chapter), according to current references in official documents.

The first observation relates to the gender distribution among students. One can observe that at the national level, the percentage of female students is almost the same with male students (53.1\% female and $46.9 \%$ male in 2012). Looking at the distribution on field of study, female students are the majority, especially in

\footnotetext{
6 See Sect. 4.
} 


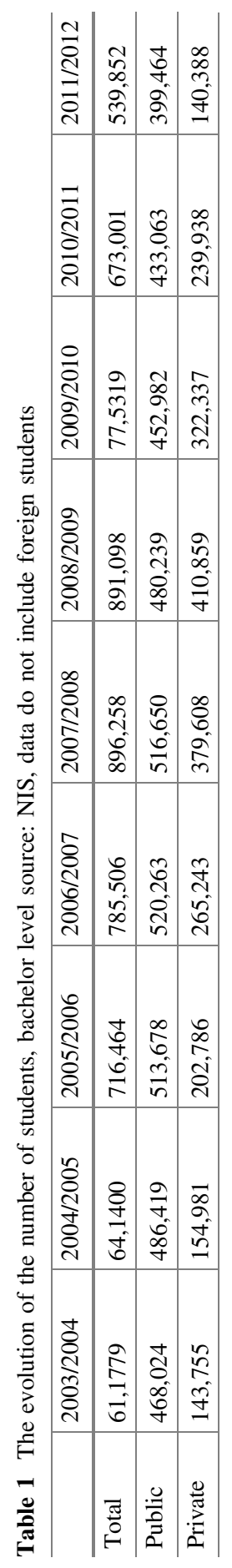


medical, pharmaceutical, humanistic, ${ }^{7}$ economic, artistic and judicial fields. By contrast, male students are predominant in technical education ${ }^{8}$ (NIS 2012). No specific gender policy was identified in order to address the above mentioned issue.

Regarding the participation of youth coming from low-income families, according to an analysis by the World Bank based on the household budget survey (2011), in 2009, only $3.8 \%$ of the youth aged 25-29 years from the $20 \%$ (quintile) poorest young people, have graduated one cycle of higher education, while $52.4 \%$ of the top $20 \%$ (quintile) most wealthy young people have graduated at the same level (World Bank 2011). In this context, even if the growth in enrolment has been impressive, there is a concern that the equity dimension was not addressed comprehensively and that the enrolment gap between the wealthiest and poorest groups has continued growing (World Bank 2013).

Youths originating from rural areas are also an under-represented group in higher education. On one hand, according to the NIS, in 2011, $45 \%$ of the total population and $51.2 \%$ of the population aged 15-19 years resides in rural areas. On the other hand, according to the same source, at the beginning of the 2011/2012 academic year, approx. $24 \%$ of the total number of students in the bachelor cycle were students which resided in a rural area. A World Bank and Ministry of Education, Research and Youth study (2008) indicates that only $3.7 \%$ of youth aged 25-29 from a rural background have graduated from higher education institutions, compared to $27.2 \%$ from an urban background. The numbers indicate clearly that it is almost nine times more likely for a young person originating from an urban background to be a higher education graduate than for a young person from a rural background.

Regarding the participation of students with disabilities in Romania, the percentage of youth with disabilities in the total youth population (aged 20-29) was $2.06 \%$ (NIS, population census of 2002). More than that, in 2012, the share of disabled people in the total number of population was $3.66 \%$ (NIS 2012). Between 2005 and 2010, at national level, the percentage of students with disabilities has never been higher than $0.07 \%$ of the total number of students, according to data collected as part of the university classification process. ${ }^{9}$ According to NIS, at bachelor level, at the beginning of the academic year 2011-2012, there were 333 disabled students in the entire Romanian student population (539.852 students) of which 309 were in public universities and 24 in private universities.

As far as Roma students are concerned, $0.6 \%$ of the Roma population aged 25-29 years graduated from higher education, compared with $24.2 \%$ for the general Romanian population and $18.7 \%$ for Hungarians living in Romania in the same age bracket (World Bank 2013).

\footnotetext{
${ }^{7}$ Humanistic education includes fields of studies like philology, history, geography, biology, chemestry and others.

8 Technical education refers to engineering sciences at university level as civil engineering, electronics, telecommunications, mechanical and others.

9 Data collection process (2011)
} 
Regarding the participation of Roma youth in secondary education, the number of Roma students admitted in high schools increased by $44.2 \%$ from $2009 / 2010$ to 2011/2012, from 2246 in 2009 to 3239 in 2011. But despite this sizeable increase in Roma participation in secondary education, only $40.1 \%$ of available subsidized study places for Roma students were taken (Ministry of National Education 2013).

Analysing the data available regarding the under-represented groups in Romanian higher education, the conclusions that can be drawn are as follows:

- Overall, there are no major differences in the proportion of females and males in the student body. Differences could be seen in the gender distribution among different fields of studies.

- Youths coming from the poorest families have far less opportunities to access higher education compared with youths coming from the richest families.

- The percentage of students from rural areas in the total number of students is far lower than the share of young people from rural areas in the total number of young people in the country.

- The percentage of students with disabilities is very low compared to the total number of youths with disabilities in the country.

- Despite the implementation of many policies, Roma access to education remains limited both at the secondary (giving the fact that almost half of the subsidized study places allocated for Roma in high schools are still vacant) and at the tertiary education levels.

\subsubsection{National Policies Regarding Equity in Higher Education}

The structure of the Romanian higher education system (in 2010) is divided between private universities (approx. $35 \%$ of the total number of students), which do not receive any funding from the government, and public universities, which enrol both students paying tuition fees (approx. $35 \%$ of the total number of students from Romania) and students supported by the state (approx. $30 \%$ of the total number of students) who are eligible for most of the equity instruments.

Three broad categories of social services are to be found in Romanian universities: social services or facilities for all students (e.g., reduced fee for local and national transportation, medical and psychological assistance, and others), social services or facilities for students in state universities (subsidized study places, student scholarships, subsidies for dorms and canteens etc.) and social services or facilities for certain categories of students (for example free dorm accommodation for some categories of students, student camps and other).

\subsubsection{Paying for Tuition Fees}

According to the National Education Law (1/2011), university education is free for the enrolment number approved annually by the Government or is paid for by the 
students, according to terms set by the law. Students who go to state universities either pay their own tuition or get their tuition costs covered by the state budget through subsidized study places. In private universities all students pay tuition fees, except for the cases where university senates decide otherwise.

From the perspective of access to higher education, it is important to analyse how state subsidized study places are distributed.

The subsidized study places are distributed to students based on the results of the admission exams organized by universities according to a general framework approved by the Ministry of National Education. ${ }^{10}$ The subsidized study places are occupied by the most academically qualified candidates from all fields of study. When calculating the general admission score, the universities can also use the following criteria: grades from the baccalaureate exam, grades obtained in highschool in relevant subjects for the higher education programmes or grades from exams organized by universities (for testing knowledge and cognitive capacities).

In most universities, at the end of the first year of undergraduate studies, the subsidized study places are redistributed annually based on academic results obtained in the previous university year.

The categories of youths who benefit from separately set subsidized study places are:

- Roma Youth ${ }^{11}$ (in the 2012/2013 university year approximately 548 places were allocated for the first year of undergraduate studies compared with 7906 places allotted for secondary education);

- High school graduates with a baccalaureate diploma from placement centres, under conditions set by each university senate ${ }^{12}$ (at least one state subsidized study place per university);

- Ethnic Romanian students from abroad based on a methodology approved by a Government Decision (in the 2012/2013 university year, at the national level, 500 subsidized study places were approved-300 with scholarships and 200 without scholarships). ${ }^{13}$

The National Education Law states that “... candidates from environments with high socio-economic risks or socially marginalized-Roma, graduated from rural high-schools or cities with less than 10000 inhabitants - may benefit from a number of guaranteed state subsidized study places, as specified by the law" but this article has not yet been operationalized in the funding methodology or in the general admission framework.

As far as tuition fees paid by students are concerned, the value of the study grant allocated by the Ministry of Education and the amount of tuition fees in both public and private universities are significantly different (see Table 2). Since the level of

10 Order no. (3544/2013).

11 Reference: Order no. (4334/2012).

12 Id. Ref. 10.

13 Id. Ref. 10. 
Table 2 Values of study grants and tuition fees

\begin{tabular}{l|l|l|l}
\hline $\begin{array}{l}\text { Field of } \\
\text { study }\end{array}$ & $\begin{array}{l}\text { Value of the study grant, for } \\
\text { studies in Romanian, bachelor } \\
\text { level—paid by the state to } \\
\text { universities (euro) }\end{array}$ & $\begin{array}{l}\text { Average tuition } \\
\text { fees in public } \\
\text { universities (euro) }\end{array}$ & $\begin{array}{l}\text { Average tuition } \\
\text { fees in private } \\
\text { universities (euro) }\end{array}$ \\
\hline $\begin{array}{l}\text { Engineering } \\
\text { sciences }\end{array}$ & 850 & 740 & 508 \\
\hline Economy & 483 & 620 & 500 \\
\hline Medicine & 1,090 & 1,450 & 522 \\
\hline
\end{tabular}

Calculations made by the authors based on public information regarding the values of tuition fees and CNFIS formula on the value of study grants

tuition fees is set by universities themselves, without any nationally-imposed standard or regulation, the value of the fees does not necessarily represent the cost of education, but rather the student's ability to pay or the "market price" of education.

In the context of equity, it is important to take into consideration the fact that, in 2010, only approximately $30 \%$ of the students in Romania (public and private) were covered through the subsidized study places, the rest paying tuition fees. ${ }^{14}$ In the meantime, the minimum salary in Romania is of about 180 Euros per month and the net medium salary is of approximately 365 euros per month (NIS 2013).

\subsubsection{The Scholarship System}

According to the National Education Law, direct financial support for students consists of scholarships or study loans. The scholarship system is analysed below in the section on what happens at the institutional level. Even though it is mentioned in the national legislation, the loan system is not functional.

\subsubsection{Subsidized Student Dorm Places}

The student dorms and canteens are subsidized by the state according to the Law of Education. The article presents below in Sect 3-Student dormitories an analysis regarding the current regulations from the institutional level and their impact on equity, focusing mainly on the categories of students that have access to dorms.

\subsubsection{Other Social and Academic Services for Students}

By looking at the current legal framework and the information available regarding its operation, it is evident that there are a variety of services that are designed to

14 Reference: Data from NIS and the National Council for Higher Education Funding (CNFIS). 
ensure an auspicious environment for students to complete and perform in a study program. However, from the authors' experience, certain services are not properly implemented and the targeted groups of students do not benefit from them. For example, according to the law, all Romanian students should benefit from reduced fees for local public transportation. Due to the existing bureaucratic procedures and the lack of concern to ensure this service at both the Ministry level and at the level of some public administrations/universities, not all students are able to receive these discounts.

Employment-related academic services (also mentioned in the Bologna Process Communiques) can include flexibility of learning paths, counselling and orientation services, alternative access routes or recognition of prior learning. Flexibility of learning is implemented at the national level through the "no attendance" system 15 and distance learning education ${ }^{16}$ and at the university/faculty level through the offering of optional or facultative courses, which vary in number and typology in each university, study fields or study program. However, in many cases, the range of optional classes is narrow, students having to choose a course from only two or three optional courses available.

\subsubsection{Other Policies with Impact on Equity}

Outside the financing policies (subsidies and financial aid) and those related to social services that have a greater impact on equity of higher education, the national policies regarding quality assurance (QA) are meant to primarily enhance the quality of education, but they also have a great impact on institutional behaviour. The most relevant procedures regarding quality assurance in Romanian higher education system are those related to the accreditation and periodical evaluation of universities. From the reference standards and common performance indicators adopted within the national QA methodology (ARACIS 2006), one could see that there are no indicators specifically targeting equity or stimulating the participation of under-represented groups, except for some standards referring to the scholarship system or to student' dorms. Moreover, it seems that, concerning admission policies, a reference standard mentions that admission is based exclusively on academic competences, limiting the possibility for one university to distribute, for example, subsidised study places for students with disabilities.

15 The Law of National Education defines "no attendance" education as being characterized by "periodical compact activities dedicated especially to synthesis courses and practice applications which implies face-to-face meetings between students and teachers in the university area, accompanied by other specific means for distance education (Art. 139, b).

16 The Law of National Education defines distance education as being characterized by "the use of electronic, communication and information resources, specific self-learning and self-assessment activities, accompanied by tutoring activities" (Art. 139, c). 


\section{Analysing Institutional Behaviour in Regard to Equity}

\subsection{General Remarks}

As described in the introduction, institutional behaviour is analysed through four case studies, using two different instruments: a self-assessment questionnaire developed by IAU, aimed at gathering information regarding institutional policies and data on equity in higher education, and study visits that included semi-structured interviews with relevant stakeholders in each university. Also regarding the student scholarship system and the subsidized student dorm places, the authors comparatively analysed the internal regulations of all the public universities.

The study visits in the four sample universities showed common characteristics that can define the institutional approach to equity in the Romanian higher education system. The most important common characteristic that was identified in all the universities was the individual approach to students needs instead of developing institutional strategies with clear objectives and action plans. The reasons for this behaviour could be: the lack of awareness of the need for and benefits of equity policies, a specific approach to policy making in which decisions are taken when a problem occurs without having a strategic framework and, last but not least, the different understanding of equity and also the lack of a national strategy and/or specific guidelines. The concept of "equity" is understood in different ways, from being understood as equality and non-discrimination to being related to the university's role in society or to market instruments design to attract new categories of students.

One of the findings is that universities are well aware of the diversity of the student population in their region. Even when they don't have any strategy or specific equity target with regard to admission and inclusiveness, they usually know the characteristics of the student population very well.

Regarding under-represented/vulnerable groups, the group whose needs are addressed most frequently by universities are students from low-income families, defined as students coming from families with an income below the national minimum wage.

Certain under-represented groups of students, such as Roma students and students with disabilities benefit from special conditions, , but the number of students from these categories is very small, considering the general need to integrate them in higher education.

Certain universities have also identified groups of students with special needs in accordance to their own special regional context or field of activity. For example, in one university from an area with a high percentage of population working outside the country, many students also work outside the country during the academic year and come back only to take the exams at the end of the academic year. The institution representatives are aware of this issue and are trying to accommodate the special needs of individual students, but there are no institutional instruments to address the needs of this special group of students (ensuring equitable access to all eligible students and quality assurance instruments-for example organizing distance 
learning programs). Also, no statements were made that would lead to the conclusion that the university is considering setting up a scholarship scheme to alleviate the financial needs of students who might otherwise need to go work abroad.

Working students represent another group of students with special needs, which also raises issues regarding the best policy approach to be taken. These students do not have time to attend courses and seminars, making it one of the most important challenges for the Romanian higher education institutions, with negative impact on the quality of education. As a general remark, the current university response to this trend seems to be that of making courses more flexible in order for students to attend (in evenings), the objective being that of retaining as many students as possible regardless of the consequences upon the quality of education (in the conditions explained in Sect. 4.2). In some cases, the need for practical experience is the reason that makes the university encourage working students.

Looking at the other groups taken into consideration by the authors, the analysis showed that students from rural areas could not be found among the priority groups and consequently no special measures or instruments were addressing their needs.

Regarding Roma students, special subsidized study places could be found in all state universities (as they are allocated from the Ministry of Education) but not all the study places were occupied and no specific institutional policy to promote recruitment for these study places was found.

In order to promote demand for their academic programmes, almost all the institutions undertake a number of actions such as outreach to secondary schools, career counselling and special courses to help high school students pass the admission exam, but these interventions do not usually take equity aspects into consideration.

\subsection{Student Scholarships System}

The Romanian Student Scholarship system is regulated by the National Education Law (1/2011) and by an earlier Government Decision. ${ }^{17}$ Conceptually, it continues the system implemented in Romania during the communist regime. The general criteria for awarding scholarships are regulated at the national level and specific criteria are decided at the institutional level.

There are two main types of scholarships: based on merit (merit scholarships) with different subcategories (study scholarships, merit scholarships and performance scholarships) and based on social needs (social scholarships) with different subcategories (social scholarships, medical scholarships). According to the law on education, the same student can receive different types of scholarships if she/he fulfils the eligibility criteria. These scholarships are awarded for the duration of a full academic year, with some exceptions that include a full calendar year in the

17 Order no. (558/1998). 
case of medical scholarships, performance scholarships, and scholarships for orphans.

The scholarships are awarded on a competitive basis, the universities taking into consideration:

- the number of scholarships resulting from dividing the overall scholarship grant given by the state to the amounts set by the university, for every type of scholarship, and

- the number of full time students who are studying in state-subsidized study places.

The total available monthly amount for scholarships in a university is calculated by multiplying a fixed sum awarded by the government (69 lei/state subsidized student place) by the above-mentioned student number. As the amount depends on the number of full time students studying in state subsidized study places, they are the only ones that are eligible to receive money from state funds. The universities can supplement the scholarship fund from their income and thus enlarge the pool of eligible students.

The general scholarship fund does not differentiate between social and merit scholarships, leaving the universities to decide how the funds are split between these categories. Thus the institutional behaviour in making this decision is a proxy for the importance given to equity matters by Romanian universities.

\subsubsection{Social Scholarships}

The state regulates the distribution of social scholarships to students from low income families (with a net monthly income per family member lower than the national minimum wage), students from orphanages or foster care, and students with predefined medical problems.

Also according to the law, the minimum amount of these scholarships should be proposed annually by National Council for Higher Education Funding (CNFIS), ${ }^{18}$ considering the fact that the scholarship must cover the minimum amounts needed for food and accommodation (Art. 223 paragraph 10).

\subsubsection{Merit Based Scholarships}

The state awards funds for scholarships as incentives to students with high academic performance (article 12, paragraph 3) and to stimulate excellence (article 223, paragraph 10). These scholarships are granted based on academic results.

\footnotetext{
18 Further, the article will use the abbreviation CNFIS for the National Council for Higher Education Funding.
} 
Performance scholarships are awarded for scientific, cultural, artistic and sports performance and the criteria for their disbursement are set at the university level.

Looking at the objectives of these types of scholarships, all legal documents that influence the granting of scholarships (National Education Law, the explanatory memorandum for the education law, secondary legislation) reiterate the following major objectives:

- The merit scholarships' aim is firstly to stimulate learning and also to stimulate performance and excellence;

- The social scholarships' aim is welfare, financial support for students with low income and social protection.

\subsubsection{Finding the Data and Doing the Math}

In Romania there were a total of 539.852 students in the first cycle (bachelor degree) in October 2012, out of which 208.965 students in state-subsidized study places (CNFIS 2013), thus given that the scholarship subsidy is 69 lei per subsidized student, the total amount available for scholarships for the first study cycle (bachelor degree) would be 14.418.585 lei (3204139 euro) per month.

Although the student population has grown with the massification of higher education, the number of subsidized study places remained relatively constant (CNFIS 2013).

According to the Education Law (Art. 223, paragraph 10) “... the minimum amount for social scholarships is proposed annually by CNFIS, considering the fact that they must cover the minimum amounts for food and accommodation". Consequently CNFIS had an Initiative to assess the minimum costs for food and accommodation at the national level. The responses received from 30 state universities revealed that:

- The national average amount in terms of the minimum cost for accommodation is 118 lei /month;

- The national average amount in terms of the minimum cost for food (lunch and dinner) is 448 lei /month, calculated at an average price of 15 lei X 30 days;

- The national average amount of the awarded social scholarships is 192 lei;

- The percentage of the funds awarded for social scholarships is $10.85(\%)$ from the total scholarship fund;

- The percentage of funds from the universities own incomes included in the scholarship funds is $7.29(\%)$;

These figures are in accordance with another study made by students in 2009 that indicated that the average cost for accommodation for a student is 124.67 lei/ month and the average cost of food is 483.49 lei/month (National Alliance of Student Organizations in Romania 2009).

Starting from the percentage of the funds awarded for social scholarships which is $10.85(\%)$ and the average value of a social scholarship which is 192 lei, one can 
estimate that for the first cycle 8,148 social scholarships could be awarded to students $(10.85 \% \times 14.418 .585 / 192)$, representing $3.9 \%$ of all first cycle students who are studying on subsidized study places. When looking at the entire population of students one can see that the social scholarship system would cover only $1.5 \%$ of all undergraduate students.

Also, looking at the data from the NIS, one can see that more that $50 \%$ of students live in the four biggest cities in Romania, which also have the highest cost of living (Bucharest $23.20 \%$, Cluj-Napoca $12.80 \%$, Iasi, $11.70 \%$, Timisoara $7.80 \%)$.

\subsubsection{Analysing How Institutions Implement the Scholarship System as an Equity Tool}

The analysis made by the authors on regulations for scholarships at the institutional level found the following results:

- 10 out of 49 state universities (that have subsidized study places) do not have a functional website, or have not made public the rules for student scholarships, in order for students to apply.

- Only nine universities out of the 39 state universities whose regulations were reviewed formally allow the combination of social scholarships with merit based ones, even though the national education law permits that.

- In only six universities out of the 39 state universities, scholarships are awarded for the full academic year according to the law, the rest award the scholarships per semester thus mitigating the impact of this instrument especially for poor students.

- 32 out of the 39 state universities formally link academic achievement criteria to eligibility for social scholarships.

\subsection{Student Dormitories}

The state gives subsidies for dorms and canteens that partially cover the living costs, the difference being paid through fees from students. The dorm places are distributed to students who do not have a permanent residence in the city where they study, based on criteria approved by university senates. The latest data available show that, in the academic year 2009/2010, $17.5 \%$ from the total number of students in state universities and $37.3 \%$ of students financed by the state were accommodated in student dorms. ${ }^{19}$

19 Reference: Data gathered in the classification of universities process. 
Giving the fact that these facilities represent support to decrease the costs of living, a question that arises in the context of equitable access to higher education refers to who is receiving this support. The article tries to answer this question by analysing the criteria on how places in dorms are distributed to students. In this regard, the regulations approved by the university Senates of 41 state universities were analysed. The analysis excludes military universities due to their specificity and those universities where regulations are not made public on the university website (five cases).

The first observation would be that the majority of universities (26) have clear procedures and criteria regarding the distribution of places in dormitories and the regulations are published on their official websites. Four universities follow a specific procedure but have no clear criteria for distribution. In other four cases, a commission establishes the criteria for distribution after analysing all requests from students. Five universities fail to publish the procedure on their web site.

In most cases, places in dormitories are available to all students of the university, regardless of whether they are financed or not by the state or whether they are enrolled in the first or the second cycle. Nevertheless, there are a few higher education institutions where only students on subsidized study places (seven institutions) or students from full-time learning programmes (four institutions) can apply for a place in the dormitories. Other universities mention in their methodology that students on subsidized study places have priority (two institutions).

In $69 \%$ of the cases, the academic performance of the students is clearly mentioned in the analysed methodologies as the first distribution criteria. In $54 \%$ of universities, the grades obtained in the previous school year, are used as a measurement instrument for the students' performance. Sometimes, additional criteria are used, such as the number of ECTS credits accumulated on extra-curricular activities in which the students were involved or their course attendance rate. It should be mentioned that there are two universities that also use the moral behaviour of students as a criterion (no further explanation on the definition of the "moral behaviour of students" are to be found in the regulations).

All methodologies mention the student categories that have priority in receiving dorm places:

- Most of the HEI's do not differentiate between disadvantaged /under-represented groups who receive support from the university in order to lower the financial pressure by reducing the living costs and other groups of students receiving support for other reasons than social needs (e.g.: foreign students that receive a state scholarship);

- $32 \%$ of the universities also mention academic performance criteria in their procedures for distribution of places to social and medical cases. They either apply the merit-based criteria to all the disadvantaged groups or only to a few categories. The merit-based criteria retrieved are: the status of the student (budget or tax), the number of ECTS accumulated, the average grade for the previous academic year etc. For the rest of the universities it is unclear whether 
they also use merit-based criteria for the distribution of places reserved to social cases.

Regarding the distribution of the total number of places in the student dormitories to performance students or to under-represented and disadvantaged groups, three types of situations were observed:

- The institution does not have a procedure for the distribution of the number of places reserved for under-represented and disadvantaged groups from the total number of places in dormitories $-78 \%$ of the universities;

- The commission (department) responsible for the distribution of the dormitory places analyses the applications (from both the students from a disadvantaged group and those with high learning performances) and decides the number of places for each of the two categories $-5 \%$ of the universities;

- The methodologies clearly specify the maximum number of places distributed on social or medical criteria-20\% of the universities. Usually this reaches a maximum of $10 \%$ of the total number of available places. There is only one exception: one higher education institution distributes 10-25\% of the available dormitory places according to social and medical criteria.

Table 3 shows the categories and percentage of students who have priority access to student dormitories, according to the universities' regulations:

Looking at the national policy documents about the access of under-represented groups in higher education and analysing the data from universities regulation, one

Table 3 Categories of students that have priority to student dorms

\begin{tabular}{l|l}
\hline & $\begin{array}{l}\% \text { of universities in which the group } \\
\text { represents a priority for dormitories }\end{array}$ \\
\hline $\begin{array}{l}\text { Orphan students and students from placement } \\
\text { centres }\end{array}$ & 76 \\
\hline $\begin{array}{l}\text { Foreign students with scholarships from the } \\
\text { Romanian state }\end{array}$ & 58.50 \\
\hline Student families & 51.20 \\
\hline $\begin{array}{l}\text { Students from low-income families } \\
\begin{array}{l}\text { Students with medical problems (especially chronic } \\
\text { diseases) }\end{array}\end{array}$ & 34.10 \\
\hline $\begin{array}{l}\text { Students proving their quality or of one of the } \\
\text { parents of"Fight for Romanian Revolution of } \\
\text { December 1989" or " hero-martyr “- with one of the } \\
\text { entries: injured, detained, injured and detained, } \\
\text { noted for outstanding deeds, accompanied by the } \\
\text { certificate signed by the President of Romania }\end{array}$ & 31.70 \\
\hline $\begin{array}{l}\text { Disabled students or some categories of disabled } \\
\text { students }\end{array}$ & 19.50 \\
\hline \begin{tabular}{l} 
Students with children \\
\hline \begin{tabular}{l} 
Students from rural areas \\
\hline
\end{tabular}
\end{tabular} & 14.60 \\
\hline
\end{tabular}


can conclude that the need to integrate specific groups as students from rural areas, students from low-income families or Roma students is not being reflected in existing university policies or regulations. Only $44 \%$ of the universities give priority in allocating dorm places to students coming from low-income families. Moreover, for this category, merit-based criteria are usually used (ex: for students to have passed all the exams). Furthermore, Roma students or students from rural areas are not a priority group for receiving places in dormitories in the universities analysed. Only one university offers dormitory places with priority to rural area students.

There are some categories of students who, according to the National Law of Education, receive free accommodation or discounts, such as students whose parents are teachers or ethnic Romanian coming from abroad. The majority of universities have some regulations for these categories, but not all of them.

\section{Conclusion and Discussion}

Even though Romania has gone through over two decades of reforms in the higher education while assuming the "massification of education" philosophy, higher education continues to be an area less accessible for the poorest or disadvantaged segments of the population. The concern for equity at the national level is mainly rhetorical, as a small dimension in otherwise largely meritocratic higher education policies. The main effect of this situation is the lack of response, at the institutional level, to the few formal existing policies on equity. The reasons for this situation have been briefly researched in this article and should be further investigated.

Starting from the Romanian commitments within the Bologna Process, the need for a strategic approach towards equity is clear, especially since, looking at the main policy documents regulating the higher education sector (government program, the Pact for Education, NRP), one can see a consensus on equity in higher education as a national priority. Currently, Romania does not have a strategy regarding the social dimension, which should include the definition of under-represented and disadvantaged groups, measurable targets for widening overall participation and for increasing the participation of under-represented groups, policies, action plans and measures to evaluate the effectiveness of the strategy.

Regardless of the commitments within the Bologna Process, targeting widening access to higher education, the reduced numbers of students and the relative unbalanced composition of the student population, a change in the national and institutional policies and behaviours is not visible in the sense of addressing this issue with specific policies. The legislative framework and the institutional practices are almost the same as during the "massification" period when the economic crisis was not affecting higher education.

Based on available data, this article identified the following main equity groups: students coming from low income families, students from rural areas, students with disabilities, Roma students and working students. Female students were not included 
as data shows an overall balanced gender distribution at the national level, albeit with some degree of gender inequality in different fields of studies.

Also, when looking at the data regarding the participation of under-represented groups, taking into consideration Romania's commitments to increasing their participation, one can see that there are not enough policies targeting those specific groups (for example students with disabilities). Moreover, from the policies that could be identified, some are not functional (for example scholarships for students from rural areas, subsidized places for students from disadvantaged areas) and the rest are implemented but not monitored in order to see if their objectives are being achieved (for example the scholarship system or the subsidized quota study places for Roma students).

The current national policies have never been analysed or revised after the mid 1990s. For example, in the case of the scholarship system, the fact that the government is pursuing two different policy objectives at the same time (encouraging academic performance and helping students with financial or medical needs) resembles an attempt to "catch two birds with one stone". Studies like the one carried out by CNFIS reveal that the actual amounts of social scholarships are too small to cover the essential expenses (food and accommodation) and universities rarely allow for the possibility of combining merit and social scholarships according to the law.

Moving from the national level to looking at the adequacy of equity policies at the institutional level, one of the main conclusions would be that the lack of a national strategy toward equity in higher education is mirrored by a similar lack of strategic approach at the institutional level. Instead, universities deal with these issues on an individual case basis. For example, even though students from rural areas or Roma students represent a priority according to the Government Programme (2013-2016), when looking at the institutional level one can see that the rural or Roma students do not represent a priority in granting financial support or access to different social services.

In some cases, the equity related institutional priorities do not seem to have an equivalent weight in the national policy framework. For example, disadvantaged groups such as students with families/children, considered as a priority in universities regulations, are not found in the national policy framework. In some cases, the institutional approaches are linked to the regional realities, the universities being more flexible for example regarding students working outside the country in one region with a very high percentage of young people in this situation.

Taking into consideration the current decrease in high school student numbers, the decreasing demographic trend and the low percentage of high school graduates with a baccalaureate diploma eligible to enter higher education, the main priority of universities is to attract and retain as many students as possible, regardless of the consequences upon the quality of education and regardless of equity considerations.

Another main conclusion would be that the merit-based criteria in the majority of universities is a precondition to benefit from equity instruments as shown in the distribution of study places, of scholarships or places in students dorms. Many universities even see equity as a concept in opposition to meritocracy. 
Significant efforts are required to stimulate discussions and awareness among all higher education stakeholders about the added value and long-term necessity of elaborating policies and strategies for developing an equitable higher education system in Romania. Equity is key in making higher education a pillar for improving socio-economic conditions for all Romanian citizens and overcoming preconceptions inherited from the pre-1990s era would be an important first step in this direction.

Open Access This chapter is distributed under the terms of the Creative Commons Attribution Noncommercial License, which permits any noncommercial use, distribution, and reproduction in any medium, provided the original author(s) and source are credited.

\section{References}

Astin, A. W., \& Oseguera, L. (2004). The declining "equity" of American higher education. Review of Higher Education: Journal of the Association for the Study of Higher Education, 27 (3), 321-341.

CNFIS. (2013). Public annual report.

Commission of the European Union. (2006). Efficiency and equity in European.

Comunique of the meeting of European Ministers in charge of Higher Education. (2001). Towards the European higher education area. Prague.

Comunique of the meeting of European Ministers in charge of Higher Education. (2007). Towards the European higher education area: Responding to challenges in a globalised world. London.

Comunique of the meeting of European Ministers in charge of Higher Education. (2009). The Bologna Process 2020 -The European Higher Education Area in the new decade. Leuven and Louvain-la-Neuv.

Comunique of the meeting of European Ministers in charge of Higher Education. (2012). Making the most of our potential: Consolidating the European higher education area. Bucharest.

Eurydice. (2009). Gender differences in education results.

Government of Romania. (2009). National reform plan for the period 2009-2013.

Government of Romania. (2013). Government program 2013-2016.

Harper, S., Patton, L., \& Wooden, O. (2009). Access and equity for African American students in higher education: A critical race historical analysis of policy efforts. The Journal of Higher, 80 (4), 389-414.

Jacobs, B., \& van der Ploeg, F. (2006). Guide to reform of higher education: a European perspective. Economic Policy, 21(47), 535-592.

National Alliance of Student Organizations in Romania. (2009). Daily student costs of living.

Niemann, Y. F., \& Maruyama, G. (2005). Inequities in higher education: Issues and promising practices in a world ambivalent about affirmative action. Journal of Social Issues, 61, 407-426.

Salmi, J., \& Bassett, R. M. (2014). The equity imperative in tertiary education: Promoting fairness and efficiency. International Review of Education (Springer)

The National Pact for Education. (2008).

World Bank. (2011). Romania Functional Review for Higher Education.

World Bank. (2013). Functional Review of the Higher Education Sector.

World Bank and Ministry of Education, Research and Youth. (2008). Introducing a Student Loan Scheme in Romania - discussion paper. 


\section{Data Used}

Data from the National Institute for Statistics (NIS), "TEMPO online" data base, extracted on September 2013, the "Statistical annual reports on higher education" and NIS communication from the official website.

Data from the National Assessment and Examination Centre, extracted in 2013.

Data from the data collection process conducted in 2011 in order to assess and classify universities and study programs: http://uefiscdi.gov.ro/articole/2535/Clasificare-universitati-si-ierarhizareprograme-de-studii.html.

Data from data from the Ministry of National Education, available in 2013.

Data from the National Council for Higher Education Funding (CNFIS), available in 2012.

\section{Legal Documents}

National Education Law no. 1/2011.

Explanatory memorandum for the education law no.1/2011.

Order no. 4334/2012 on the distribution of the tuition number for university undergraduate Studies for Admission in the 2012-2013 university year.

Order no. 558/1998 on the amendments to annexes 1 and 2 of the Order no. 455/1997 on the establishment of the general criteria regarding the distribution of scholarship and other financial support for high school students, students and learners from the day to day state education.

Order no. 77/2009 on the approval of enrolment for public schools and higher education institutions in school/university year 2009-2010.

Order no. 3544/2013 on the general admission framework for bachelor, master and $\mathrm{PhD}$ studies in university year 2013/2014.

ARACIS (2006). External evaluation methodology, standards, reference standards and performance indicators.

\section{Online Resources}

"Higher Education Evidence Based Policy Making: a necessary premise for progress in Romania" project implemented by the Executive Agency for Higher Education, Innovation and Development Funding (UEFISCDI) - http://www.politici-edu.ro/?lang=en. 